\title{
Preparation of 2,6-dialkoxybenzaldehydes
}

\author{
Alan R. Katritzky, ${ }^{a}{ }^{a}$ Hai-Ying He, ${ }^{a}$ Qiuhe Long, ${ }^{a}$ and Allan L. Wilcox ${ }^{b}$ \\ ${ }^{a}$ Center for Heterocyclic Chemistry, Department of Chemistry, University of Florida, \\ P. O. Box 117200, Gainesville, FL 32611-7200, USA \\ ${ }^{b}$ Centaur Pharmaceuticals, Inc., 484 Oakmead Parkway, Sunnyvale, CA 94086, USA \\ E-mail: katritzky@chem.ufl.edu \\ (received 03 Jan 01; accepted 01 Jan 99; published on the web 07 Nov 01)
}

\begin{abstract}
Lithiation of 1,3-dialkoxybenzenes with $n$-BuLi, followed by formylation with DMF, furnished solely 2,6-dialkoxybenzaldehydes with high regioselectivity. Using this key step, different approaches have been developed for novel symmetrical and unsymmetrical 2,6dialkoxybenzaldehydes.
\end{abstract}

Keywords: 1,3-Dialkoxybenzenes, 2,6-dialkoyxbenzaldehydes, lithiation, formylation

\section{Introduction}

Dialkoxybenzaldehydes are useful and important precursors for pharmaceutical industry and for organic synthesis in general. O-Alkylations of 2,3- or 2,4-dihydroxy-benzaldehydes with benzyl bromide or ethyl iodide were reported to produce 2,3-dibenzyloxybenzaldehydes ${ }^{1}$ or 2,4dibenzyloxy- and 2,4-diethoxy-benzaldehydes. ${ }^{2-4}$ However, this route is not appropriate for the preparation of 2,6-dialkoxybenzaldehydes due to lack of the commercially available 2,6dihydroxybenzaldehyde. Even if 2,6-dihydroxybenzaldehyde is available, its alkylation with alkyl halides is not expected to generate unsymmetrical 2,6-dialkoxybenzaldehydes because of poor regioselectivity. Although the direct formylation of an aromatic ring with hexamethylenetetramine (HMTA) in acetic acid and/or trifluoroacetic acid is a known method to introduce a formyl group into an aromatic ring, ${ }^{5-10}$ the formylation of 1,3-dialkoxybenzenes with HMTA is not appropriate for preparation of 2,6-dialkoxybenzaldehydes due to poor regioselectivity (one example will be discussed in this paper). A very recent paper reported the formylation of phenol derivatives with formaldehyde in the presence of KSF-Et3N, but the substituents attached to the benzene ring are limited to alkyl groups. ${ }^{11}$ To our knowledge, no general method has previously been reported to prepare 2,6-dialkoxybenzaldehydes. In this paper, we develop several approaches for the title compounds. 


\section{Results and Discussion}

Our first approach was to use the ability of certain 1,3-substituents on aromatic systems to direct metallation at a position ortho to both of these groups using organolithium reagents. This phenomenon is of synthetic importance since electrophilic attack on aryllithium intermediates is a useful method for the functionalization of aromatic compounds. Therefore, many papers have reported the factors which control the regioselectivity and efficiency of lithiation of aromatic substrates. ${ }^{12}$ Numerous functional groups are known to promote ortho-lithiation. ${ }^{13,}{ }^{14}$ However, with many of these groups, difficulties may arise due to lack of discrimination between nonequivalent ortho positions or between the ring positions and other acidic sites within the substrates. ${ }^{15}$

An early investigation revealed that lithiation can occur selectively at the common ortho site of 1,3-dialkoxybenzenes. ${ }^{15}$ Encouraged by these results, we first synthesized symmetrical 2,6dialkoxybenzaldehydes $\mathbf{3 a}$ and $\mathbf{3 b}$ in two steps by $O$-alkylation of benzene-1,3-diol (1) in the presence of potassium carbonate with an excess alkyl iodide, followed by the lithiation and subsequent formylation of the corresponding intermediate symmetrical 1,3-dialkoxybenzenes 2a and $\mathbf{2 b}$ (Scheme 1). The ${ }^{1} \mathrm{H}$ NMR spectra (no singlet proton peak in the aromatic region) and ${ }^{13} \mathrm{C}$ NMR spectra (four aromatic carbon peaks determining the molecular symmetry) clearly prove that the formyl group is introduced into the desired position with high regioselectivity between the two ortho directing alkoxy groups. No regio-isomers with the formyl group at other positions of the benzene ring were detected.

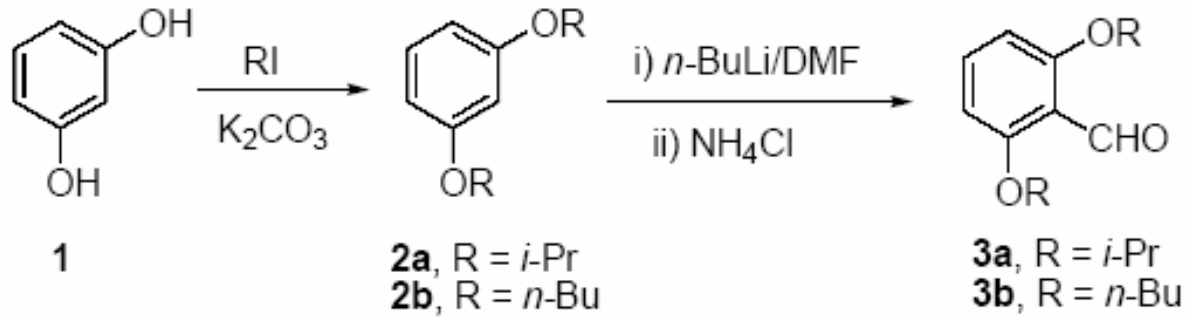

\section{Scheme 1}

We found that the formylation of 1,3-diphenoxybenzene (4) with $n$-BuLi/DMF gave a single regio-isomer, 2,6-diphenoxybenzaldehyde (5), in 70\% yield. By contrast, the formylation of 4 with HMTA in the mixed-solvent $(\mathrm{CF} 3 \mathrm{COOH} / \mathrm{CH} 3 \mathrm{COOH}=1: 1)$ produced solely 2,4diphenoxybenzaldehyde (6) in 57\% yield. The structures of $\mathbf{5}$ and $\mathbf{6}$ were clearly confirmed by their ${ }^{13} \mathrm{C}$ NMR spectra. For $\mathbf{5}$, only eight carbon peaks are found in the aromatic region due to its symmetrical structure; while for $\mathbf{6}$, lack of symmetry in the structure results in fourteen carbon peaks. The two phenoxy groups in $\mathbf{4}$ activate the 2-position proton for ortho-lithiation by n-BuLi; however, when 4 reacts with the larger reagent HMTA, significant stereo hindrance at the 2position by the two phenoxy groups directs the formylation to the less hindered 4-position. Therefore, the formylation of $\mathbf{4}$ with $n$-BuLi/DMF or HMTA afforded 2,6- 
diphenoxybenzaldehyde (5) or 2,4-diphenoxybenzaldehyde (6), respectively, with high regioselectivity (Scheme 2).

For unsymmetrical 2-methoxy-6-alkoxybenzaldehydes, we used commercially available 3methoxyphenol (7) as the starting material. O-Alkylation of 7 with the alkyl iodides readily produced 1-methoxy-3-alkoxybenzenes $\mathbf{8 a}-\mathbf{c}$, which were subsequently lithiated and formylated as described above to generate 2-methoxy-6-alkoxybenzaldehydes 9a-c in moderate yields (Scheme 3 and Table 1). The structures of $9 \mathbf{a}-\mathbf{c}$ were confirmed by their ${ }^{1} \mathrm{H}$ NMR (no singlet peak in the aromatic region) and ${ }^{13} \mathrm{C}$ NMR spectra. Notably, entry $\mathrm{d}$ in Table 1 shows that although the alkylation of 7 with benzyl bromide gave $75 \%$ yield of 1-methoxy-3benzyloxybenzene (8d), treatment of $8 \mathbf{d}$ with $n$-BuLi/DMF did not furnish the desired product 2benzyloxy-6-methoxybenzaldehyde (9d). This could be rationalized by the high acidity of the benzyl hydrogens, which can be competitively deprotoned by $n$-BuLi, thus causing the formation of unexpected by-products. Therefore, another strategy was developed for preparation of 9d.

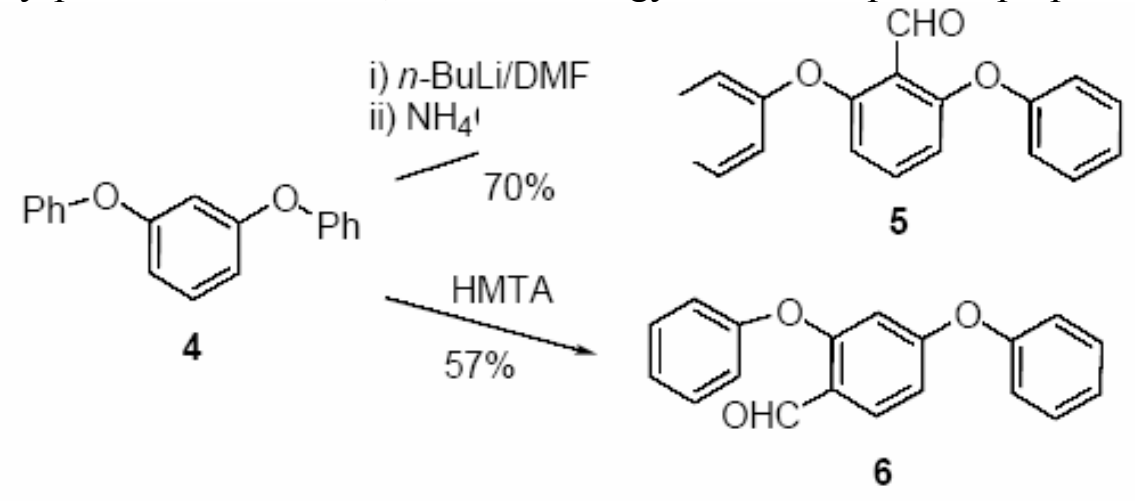

\section{Scheme 2}

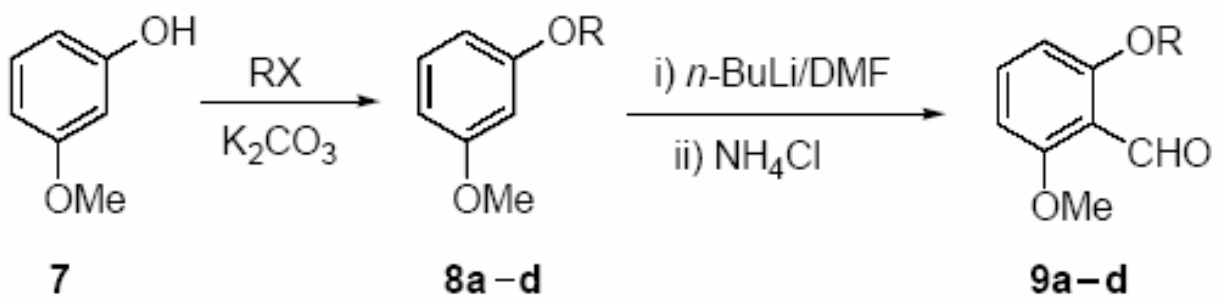

Scheme 3

Table 1. Preparation of 2-alkoxy-6-methoxybenzaldehydes 9a-c

\begin{tabular}{cccc}
\hline Entry & $\mathrm{RX}$ & $\mathrm{Y} \mathrm{( \% )} \mathrm{of} \mathrm{8}$ & $\mathrm{Y}(\%)$ of $\mathbf{9}$ \\
\hline a & $n$-PrI & 70 & 60 \\
b & $i$-PrI & 68 & 57 \\
c & $n$ - $8 \mathrm{CH}_{17} \mathrm{I}$ & 90 & 53 \\
d & $\mathrm{PhCH}_{2} \mathrm{Br}$ & 75 & 0 \\
\hline
\end{tabular}


The prerequisite starting material for preparation of $9 \mathrm{~d}$ is obtained by methodology from Zacharie's work. ${ }^{16}$ 2-Hydroxy-6-methoxybenzaldehyde (12) was obtained from 3methoxyphenol (7) in three steps in overall 44\% yield (reported yield ${ }^{16}: 45 \%$ ) (Scheme 4). Treatment of 12 with benzyl, allyl and propargyl bromide and ethyl 2-bromoacetate in the presence of potassium carbonate produced unsymmetrical 2-alkoxy-6-methoxybenzaldehydes $9 \mathbf{d}-\mathbf{g}$ in $63 \%-75 \%$ yields. The structures of $\mathbf{9 d}-\mathbf{g}$ were confirmed by their ${ }^{1} \mathrm{H},{ }^{13} \mathrm{C}$ NMR spectra and elemental analyses or HRMS results. The method is therefore useful for preparation of 2-alkoxy-6methoxybenzaldehydes with substituents containing acidic hydrogens. However, there is an obvious limitation that the 6-position has to be occupied by a methoxy group due to the starting material 3-methoxyphenol (7).
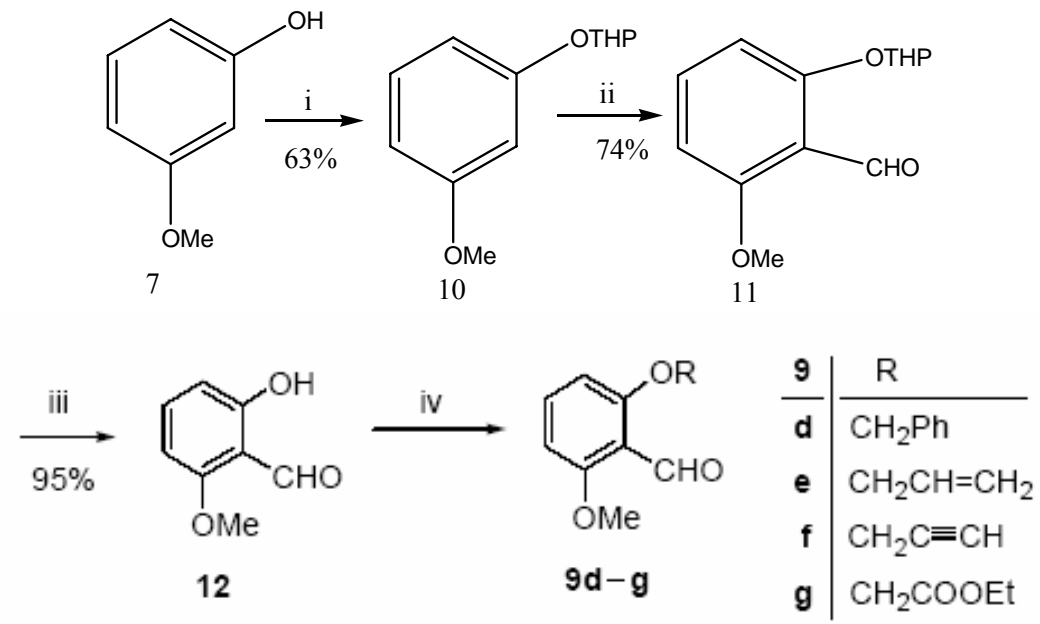

i) 3,4-dihydro-2H-pyran; ii) $n$-BuLi/DMF, $\mathrm{Et}_{2} \mathrm{O}$; iii) $\mathrm{H}_{3} \mathrm{O}^{+}$; iv) $\mathrm{RBr}, \mathrm{K}_{2} \mathrm{CO}_{3}$

\section{Scheme 4}

Our preparation of other novel unsymmetrical 2,6-dialkoxybenzaldehydes from benzene-1,3diol (1) was based on Klarmann's work. ${ }^{17}$ The selective $O$-alkylation of 1 with one equivalent of ethyl iodide in the presence of $25 \% \mathrm{KOH}$ aqueous solution for $5 \mathrm{~h}$ gave a mixture of 3ethoxyphenol (13a), 1,3-diethoxybenzene and starting material 1 in a 2:1:1 ratio (determined by GC). Intermediate 13a was isolated in $50 \%$ yield by column chromatography. Treatment of 13a

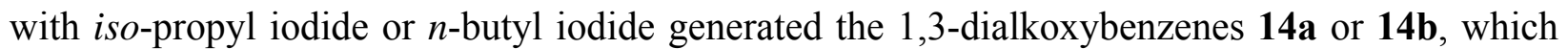
were subsequently lithiated and formylated to furnish 2-iso-propoxy-6-ethoxybenzaldehyde (15a) or 2-butoxy-6-ethoxybenzaldehyde (15b), respectively. Similar treatment of 1 with $n$-butyl iodide gave $47 \%$ of 3 butoxyphenol (13b), which was reacted with $n$-octyl iodide to generate 1 octyloxy-3-butoxybenzene (14c). Formylation of 14c with $n$-BuLi/DMF afforded 2-octyloxy-6butoxybenzaldehyde (15c) (Scheme 5). For the introduction of a benzyloxy group at the 2position, we protected the hydroxy group in 13b with 3,4-dihydro-2H-pyran to obtain butyl 3(tetrahydro-2H-pyran-2-yloxy)phenyl ether (16). Treatment of 16 with $n$-BuLi/DMF introduced the formyl group into the desired position between the two alkoxy groups. Deprotection of 
intermediate 17 by acid hydrolysis gave 2-hydroxy-6-butoxybenzaldehyde (18), which easily underwent $O$-alkylation with benzyl bromide to afford 2-benzyloxy-6-butoxybenzaldehyde (19) (Scheme 5).

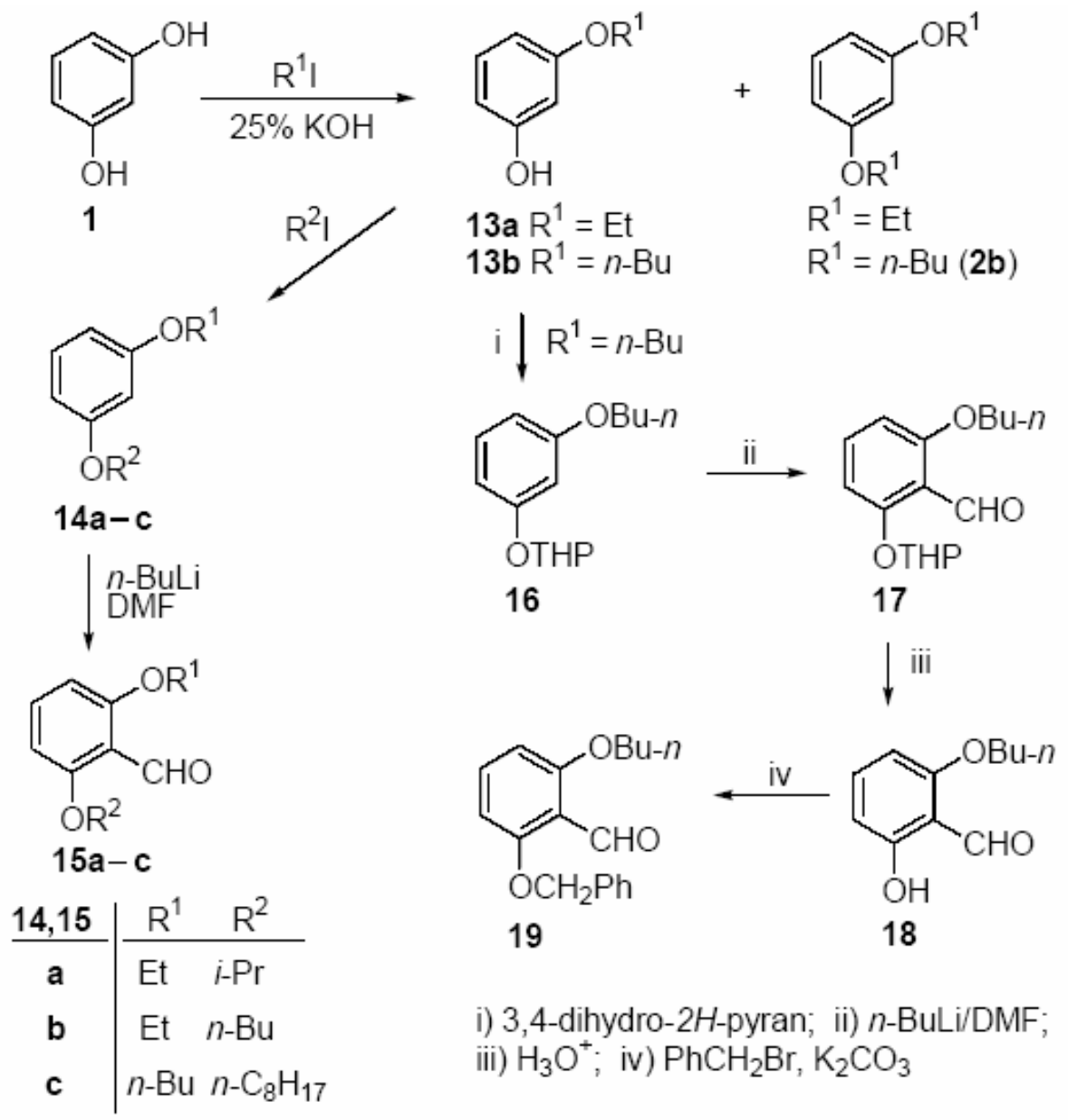

\section{Scheme 5}

In summary, several approaches have been developed for the preparation of symmetrical and unsymmetrical 2,6-dialkoxybenzaldehydes. The key step is the highly regioselective introduction of the formyl group into the desired position between two ortho directing alkoxy groups by the lithiation of 1,3-dialkoxybenzenes with $n$-BuLi, followed by formylation with DMF.

\section{Experimental Section}

General Procedures. THF was distilled from sodium-benzophenone prior to use. Melting points were determined using a Bristoline hot-stage microscope and are uncorrected. ${ }^{1} \mathrm{H}$ and ${ }^{13} \mathrm{C}$ NMR spectra (300 MHz and $75 \mathrm{MHz}$ respectively) were recorded on a Gemini 300 NMR spectrometer in $\mathrm{CDCl}_{3}$ (with TMS for ${ }^{1} \mathrm{H}$ and $\mathrm{CDCl}_{3}$ for ${ }^{13} \mathrm{C}$ as the internal reference). Elemental analyses were performed on a Carlo Erba-1106 instrument. Column chromatography was performed on 
silica gel. All of the reactions were carried out under $\mathrm{N}_{2}$.

General procedure for the preparation of 1,3-dialkoxybenzene $2 \mathrm{a}$ and $2 \mathrm{~b}$ from $\mathrm{O}$-alkylation of benzene-1,3-diol (1) with alkyl iodide

A mixture of benzene-1,3-diol $(1 ; 1.10 \mathrm{~g}, 10 \mathrm{mmol})$, iso-propyl iodide or $n$-butyl iodide (20 mmol) and $\mathrm{K}_{2} \mathrm{CO}_{3}(6.9 \mathrm{~g}$, anhydrous) was refluxed in dry acetone $(50 \mathrm{~mL})$. After refluxing for $5 \mathrm{~h}$, more iso-propyl iodide or $n$-butyl iodide $(20 \mathrm{mmol})$ was added to the mixture. Time for complete reaction (monitored by GC analysis) for $2 \mathrm{a}$ and $2 \mathrm{~b}$ was $12 \mathrm{~h}$ and $14 \mathrm{~h}$, respectively (GC purity for $2 \mathrm{a}: 58 \%$; for $2 \mathrm{~b}: 64 \%)$. The cooled mixture was poured into water $(60 \mathrm{~mL})$ and extracted with EtOAc $(3 \times 20 \mathrm{~mL})$. The combined extracts were washed with water and dried over anhyd $\mathrm{Na}_{2} \mathrm{SO}_{4}$. After removal of solvent in vacuo, the product was purified by column chromatography with hexanes/EtOAc (4:1 to $2: 1)$ as an eluent to give 1,3-di-iso-propoxybenzene (2a; $1.07 \mathrm{~g}, 55 \%)$, 1,3-dibutoxybenzene $(2 \mathrm{~b} ; 1.33 \mathrm{~g}, 60 \%)$, respectively. The GC purity of $2 \mathrm{a}, 2 \mathrm{~b}$ was more than $97 \%$.

General procedure for the formylation of symmetrical 1,3-dialkoxybenzene $2 \mathrm{a}, \mathbf{2 b}$ and 1,3 diphenoxybenzene (4) with $\boldsymbol{n}$-BuLi/DMF

To a stirred solution of 1,3-dialkoxybenzene $2 \mathrm{a}, 2 \mathrm{~b}(10 \mathrm{mmol})$ or 1,3-diphenoxybenzene (4; $2.62 \mathrm{~g}, 10 \mathrm{mmol})$ in dry $\mathrm{THF}(60 \mathrm{~mL})$ at $0{ }^{\circ} \mathrm{C}$, was added dropwise $n$-BuLi $(8 \mathrm{~mL}, 1.5 \mathrm{M}$ in hexanes). The mixture was stirred at $\mathrm{rt}$ for $2 \mathrm{~h}$ and then DMF (1.83 g, $25 \mathrm{mmol})$ was added. After $2 \mathrm{~h}$, the mixture was poured into water. The THF phase was separated and the water phase was extracted with ether $(3 \times 30 \mathrm{~mL})$. The combined organic phase was dried over anhyd $\mathrm{Na}_{2} \mathrm{SO}_{4}$. After removal of solvent in vacuo, the product was purified by column chromatography with hexanes/EtOAc (9:1 to 6:1) as an eluent to afford symmetrical 2,6-dialkoxybenzaldehydes 3a, 3b or 2,6-diphenoxybenzaldehyde (5). 2,6-Di-iso-propoxybenzaldehyde (3a): colorless oil; yield, $1.80 \mathrm{~g}(81 \%) ;{ }^{1} \mathrm{H}$ NMR $\delta 1.36\left(\mathrm{~d}, J=6.0 \mathrm{~Hz}, 12 \mathrm{H}, 4 \times-\mathrm{CH}_{3}\right), 4.58(\mathrm{qq}, J=6.0,6.0 \mathrm{~Hz}, 2 \mathrm{H}, 2 \times-$ OCH-), 6.52 (d, $J=8.5 \mathrm{~Hz}, 2 \mathrm{H}, \mathrm{H}-3$ and H-5), 7.33 (dd, $J=8.5,8.5 \mathrm{~Hz}, 1 \mathrm{H}, \mathrm{H}-4), 10.49$ (s, 1H, CHO); ${ }^{13} \mathrm{C}$ NMR $\delta 21.9,71.3,106.0$ (C-3 and C-5), 116.4 (C-1), 135.0 (C-4), 160.5 (C-2 and C6), $189.6(\mathrm{C}=\mathrm{O})$. HRMS Calcd for $\mathrm{C}_{13} \mathrm{H}_{19} \mathrm{O}_{3}$ : $223.1334(\mathrm{M}+1)$, found: 223.1358.

2,6-Dibutoxybenzaldehyde (3b). Colorless oil; yield, $1.90 \mathrm{~g}(76 \%) ;{ }^{1} \mathrm{H}$ NMR $\delta 0.94$ (t, $J=7.5$ $\left.\mathrm{Hz}, 6 \mathrm{H}, 2 \times-\mathrm{CH}_{3}\right), 1.47-1.54(\mathrm{~m}, 4 \mathrm{H}), 1.75-1.84(\mathrm{~m}, 4 \mathrm{H}), 3.99\left(\mathrm{t}, J=6.5 \mathrm{~Hz}, 4 \mathrm{H}, 2 \times-\mathrm{OCH}_{2^{-}}\right)$, $6.50(\mathrm{~d}, J=8.5 \mathrm{~Hz}, 2 \mathrm{H}, \mathrm{H}-3$ and H-5), 7.34 (dd, $J=8.5,8.5 \mathrm{~Hz}, 1 \mathrm{H}, \mathrm{H}-4), 10.54$ (s, 1H, CHO); ${ }^{13} \mathrm{C}$ NMR $\delta$ 13.6, 19.0, 30.9, 68.3, 104.2 (C-3 and C-5), 114.4 (C-1), $135.4(\mathrm{C}-4), 161.3$ (C-2 and C-6), $188.9(\mathrm{C}=\mathrm{O})$. HRMS Calcd for $\mathrm{C}_{15} \mathrm{H}_{23} \mathrm{O}_{3}: 251.1647(\mathrm{M}+1)$, found: 251.1657.

2,6-Diphenoxybenzaldehyde (5). Colorless needles; yield, $2.29 \mathrm{~g}(79 \%)$; mp 88-89 ${ }^{\circ} \mathrm{C}$; ${ }^{1} \mathrm{H}$ NMR $\delta 6.55(\mathrm{~d}, J=8.3 \mathrm{~Hz}, 2 \mathrm{H}), 7.06-7.10(\mathrm{~m}, 4 \mathrm{H}), 7.14-7.19(\mathrm{~m}, 2 \mathrm{H}), 7.28-7.40(\mathrm{~m}, 5 \mathrm{H})$, 10.60 (s, 1H, CHO); ${ }^{13} \mathrm{C}$ NMR $\delta=112.6$ (C-3 and C-5), 118.3 (C-1), 119.6, 124.3, 129.9, 135.1 (C-4), 156.0, 159.8 (C-2 and C-6), $188.1(\mathrm{C}=\mathrm{O})$. Anal. Calcd for $\mathrm{C}_{19} \mathrm{H}_{14} \mathrm{O}_{3}: \mathrm{C}, 78.61 ; \mathrm{H}, 4.86$. Found: C 78.42; H, 4.78

Procedure for the formylation of 1,3-diphenoxybenzene (4) with HMTA. A mixture of 1,3- 
diphenoxybenzene (4; $2.62 \mathrm{~g}, 10 \mathrm{mmol})$ and HMTA (3.22 $\mathrm{g}, 23 \mathrm{mmol})$ in the mixed-solvent $\left(\mathrm{CF}_{3} \mathrm{COOH} / \mathrm{CH}_{3} \mathrm{COOH}=1: 1,60 \mathrm{~mL}\right)$ was heated to reflux for $3 \mathrm{~h}$. After cooling, the mixture was poured into water and extracted with EtOAc. The combined extracts were washed with water and dried over anhyd $\mathrm{Na}_{2} \mathrm{SO}_{4}$. After removal of the solvent in vacuo, the product was purified by column chromatography with hexanes/EtOAc (6:1) as an eluent to give 2,4diphenoxybenzaldehyde (6).

2,4-Diphenoxybenzaldehyde (6). Colorless needles; yield, $1.65 \mathrm{~g}(57 \%)$; mp 52-53 ${ }^{\circ} \mathrm{C}$; ${ }^{1} \mathrm{H}$ NMR $\delta 6.46(\mathrm{~s}, 1 \mathrm{H}, \mathrm{H}-3), 6.65(\mathrm{~d}, J=6.7 \mathrm{~Hz}, 1 \mathrm{H}), 7.00-7.18(\mathrm{~m}, 6 \mathrm{H}), 7.31-7.39(\mathrm{~m}, 4 \mathrm{H}), 7.88$ $(\mathrm{d}, J=8.7 \mathrm{~Hz}, 1 \mathrm{H}), 10.39$ (s, 1H, CHO); ${ }^{13} \mathrm{C}$ NMR $\delta 106.8,111.9,119.4,120.2,121.8,124.5$, 124.9 , 130.0, 130.04, 130.2, 154.7, 155.8, 161.7, 164.1, $187.8(\mathrm{C}=\mathrm{O})$. Anal. Calcd for $\mathrm{C}_{19} \mathrm{H}_{14} \mathrm{O}_{3}$ : C, 78.61; H, 4.86. Found: C, 78.97; H 4.87.

\section{General procedure for the preparation of 1-alkoxy-3-methoxybenzenes 8a-d from 7}

A mixture of 3-methoxyphenol $(7 ; 1.24 \mathrm{~g}, 10 \mathrm{mmol})$, an appropriate alkyl iodide or benzyl bromide $(25 \mathrm{mmol})$ and $\mathrm{K}_{2} \mathrm{CO}_{3}(4.5 \mathrm{~g}$, anhydrous) was refluxed in dry acetone $(50 \mathrm{~mL})$. The reaction time monitored by TLC for $\mathbf{8 a - d}$ was about $10 \mathrm{~h}$. The cooled mixture was poured into water $(60 \mathrm{~mL})$ and extracted with EtOAc $(3 \times 20 \mathrm{~mL})$. The combined extracts were washed with water and dried over anhyd $\mathrm{Na}_{2} \mathrm{SO}_{4}$. After removal of solvent in vacuo, the product was purified by column chromatography with hexanes/EtOAc (10:1 to 4:1) as an eluent to give 1-propoxy-3methoxybenzene (8a; 1.16 g, 70\%), 1-iso-propoxy-3-methoxybenzene (8b; 1.13 g, 68\%), 1octyloxy-3-methoxybenzene (8c; $2.13 \mathrm{~g}, 90 \%)$ and 1-benzyloxy-3-methoxybenzene $(\mathbf{8 d} ; 1.61 \mathrm{~g}$, $75 \%$ ), respectively. The GC purity of $8 \mathbf{a}-\mathbf{d}$ was more than $96 \%$.

\section{General procedure for the formylation of 1-alkoxy-3-methoxybenzenes 8a-d with $n$ - BuLi/DMF}

To a stirred solution of 1-alkoxy-3-methoxybenzene 8a-c $(10 \mathrm{mmol})$ in dry THF $(60 \mathrm{~mL})$ at $0{ }^{\circ} \mathrm{C}, \mathrm{n}$-BuLi ( $8 \mathrm{~mL}, 1.5 \mathrm{M}$ in hexanes) was added dropwise. The mixture was stirred at $\mathrm{rt}$ for $2 \mathrm{~h}$ and then DMF (1.83 g, $25 \mathrm{mmol}$ ) was added. After $2 \mathrm{~h}$, the mixture was poured into water. The THF phase was separated and the water phase was extracted with $\mathrm{CH}_{2} \mathrm{Cl}_{2}(3 \times 30 \mathrm{~mL})$. The combined organic phase was dried over anhyd $\mathrm{Na}_{2} \mathrm{SO}_{4}$. After removal of solvent in vacuo, the product was purified by column chromatography with hexanes/EtOAc (5:1) as an eluent to afford 2-alkoxy-6-methoxybenzaldehydes 9a-c. Formylation of 8d with $n$-BuLi/DMF failed to give the desired product 9d.

2-Propoxy-6-methoxybenzaldehyde (9a). colorless oil; yield, $1.17 \mathrm{~g}(60 \%) ;{ }^{1} \mathrm{H} \mathrm{NMR} \delta 1.02(\mathrm{t}$, $\left.J=7.4 \mathrm{~Hz}, 3 \mathrm{H},-\mathrm{CH}_{3}\right), 1.81-1.87(\mathrm{~m}, 2 \mathrm{H}), 3.88\left(\mathrm{~s}, 3 \mathrm{H},-\mathrm{OCH}_{3}\right), 3.97(\mathrm{t}, J=6.4 \mathrm{~Hz}, 2 \mathrm{H}$, - $\left.\mathrm{OCH}_{2}-\right), 6.53$ (d, $\left.J=8.5 \mathrm{~Hz}, 1 \mathrm{H}\right), 6.54$ (d, $\left.J=8.5 \mathrm{~Hz}, 1 \mathrm{H}\right), 7.39$ (dd, $\left.J=8.5,8.5 \mathrm{~Hz}, 1 \mathrm{H}, \mathrm{H}-4\right)$, 10.53 (s, 1H, CHO); ${ }^{13} \mathrm{C}$ NMR $\delta 10.3,22.2,55.8,70.1,103.4,104.4,114.0(\mathrm{C}-1), 135.7$ (C-4), 161.2, 162.1, $189.2(\mathrm{C}=\mathrm{O})$. Anal. Calcd for $\mathrm{C}_{11} \mathrm{H}_{14} \mathrm{O}_{3}$ : C, 68.02; H,7.27. Found: C, 67.98; H, 7.66 . 
2-iso-Propoxy-6-methoxybenzaldehyde (9b). colorless oil; yield, $1.11 \mathrm{~g}(57 \%) ;{ }^{1} \mathrm{H}$ NMR $\delta$ $1.36\left(\mathrm{~d}, J=6.2 \mathrm{~Hz}, 6 \mathrm{H}, 2 \times \mathrm{CH}_{3}\right), 3.88\left(\mathrm{~s}, 3 \mathrm{H}, \mathrm{OCH}_{3}\right), 4.63$ (qq, $\left.J=6.0,6.0 \mathrm{~Hz}, 1 \mathrm{H},-\mathrm{OCH}-\right)$, $6.53(\mathrm{~d}, J=8.5 \mathrm{~Hz}, 1 \mathrm{H}), 6.58(\mathrm{~d}, J=8.5 \mathrm{~Hz}, 1 \mathrm{H}), 7.38(\mathrm{dd}, J=8.5,8.5 \mathrm{~Hz}, 1 \mathrm{H}, \mathrm{H}-4), 10.51$ (s, $1 \mathrm{H}, \mathrm{CHO}) ;{ }^{13} \mathrm{C}$ NMR $\delta$ 22.4, 56.4, 71.9, 104.0, 106.7, 115.7 (C-1), 136.1 (C-4), 161.7, 162.0, $190.2(\mathrm{C}=\mathrm{O})$. Anal. Calcd for $\mathrm{C}_{11} \mathrm{H}_{14} \mathrm{O}_{3}$ : C, 68.02; H, 7.27. Found: C, 67.80; H, 7.47.

2-Octyloxy-6-methoxybenzaldehyde (9c). colorless oil; yield, $1.40 \mathrm{~g}(53 \%) ;{ }^{1} \mathrm{H} \mathrm{NMR} \delta 0.86(\mathrm{t}$, $\left.J=7.1 \mathrm{~Hz}, 3 \mathrm{H},-\mathrm{CH}_{3}\right), 1.28-1.30(\mathrm{~m}, 8 \mathrm{H}), 1.44-1.48(\mathrm{~m}, 2 \mathrm{H}), 1.79-1.84(\mathrm{~m}, 2 \mathrm{H}), 3.87$ (s, 3H, $\left.\mathrm{OCH}_{3}\right), 4.02\left(\mathrm{t}, J=6.5 \mathrm{~Hz}, 2 \mathrm{H},-\mathrm{OCH}_{2}-\right), 6.54(\mathrm{~d}, J=8.5 \mathrm{~Hz}, 1 \mathrm{H}), 6.55(\mathrm{~d}, J=8.5 \mathrm{~Hz}, 1 \mathrm{H}), 7.39$ (dd, $J=8.5,8.5 \mathrm{~Hz}, 1 \mathrm{H}, \mathrm{H}-4), 10.53$ (s, 1H, CHO); ${ }^{13} \mathrm{C} \mathrm{NMR} \delta 14.0,22.5,25.9,28.9,29.1,29.2$, 31.7, 55.8, 68.8, 103.5, 104.4, 114.1 (C-1), 135.9 (C-4), 161.3, 162.3, 189.5 (C=O). Anal. Calcd for $\mathrm{C}_{16} \mathrm{H}_{24} \mathrm{O}_{3}$ : C, 72.69; H, 9.15. Found: C,72.82; H, 9.37 .

\section{General procedure for the preparation of 2-alkoxy-6-methoxybenzaldehydes 9d-g from 7}

2-Hydroxy-6-methoxybenzaldehyde (12) was obtained from 3-methoxyphenol (7) in three steps in total $44 \%$ yield, according to the reported procedure (reported yield ${ }^{16}: 45 \%$ ). A mixture of 2hydroxy-6-methoxybenzaldehyde $(12 ; 1.52 \mathrm{~g}, 10 \mathrm{mmol})$, an appropriate alkyl bromide (25 mmol) and $\mathrm{K}_{2} \mathrm{CO}_{3}(4.5 \mathrm{~g}$, anhydrous $)$ in acetone $(50 \mathrm{~mL})$ was refluxed for $4 \mathrm{~h}$. The cooled mixture was poured into water $(60 \mathrm{~mL})$ and extracted with EtOAc $(3 \times 20 \mathrm{~mL})$. The combined extracts were washed with water and dried over anhyd $\mathrm{Na}_{2} \mathrm{SO}_{4}$. After removal of solvent in vacuo, the product was purified by column chromatography with hexanes/EtOAc (4:1 to 2:1) as an eluent to give $\mathbf{9 d - g}$.

2-Benzyloxy-6-methoxybenzaldehyde (9d). colorless needles (from $\mathrm{CHCl}_{3} /$ hexane); yield, $1.53 \mathrm{~g}(63 \%) ; \operatorname{mp} 68-69{ }^{\circ} \mathrm{C} ;{ }^{1} \mathrm{H}$ NMR $\delta 3.86$ (s, 3H, $\left.-\mathrm{OCH}_{3}\right), 5.14$ (s, 2H, $\left.\mathrm{PhCH}_{2^{-}}\right), 6.55-6.62$ (m, 2H), 7.30-7.45 (m, 6H), 10.59 (s, 1H, CHO); ${ }^{13} \mathrm{C}$ NMR $\delta 55.9,70.4,104.0,105.1,114.5(\mathrm{C}-$ 1), 126.8, 127.8, 128.4, $135.7(\mathrm{C}-4), 136.1,161.4,161.6,189.2(\mathrm{C}=\mathrm{O})$. Anal. Calcd for $\mathrm{C}_{15} \mathrm{H}_{14} \mathrm{O}_{3}$ : C, 74.36; H, 5.82. Found: C, 74.28; H, 5.97.

2-Allyloxy-6-methoxybenzaldehyde (9e). colorless oil; yield, $1.38 \mathrm{~g} \mathrm{(72 \% );}{ }^{1} \mathrm{H}$ NMR $\delta 4.02$ (s, $\left.3 \mathrm{H},-\mathrm{OCH}_{3}\right), 4.74-4.77\left(\mathrm{~m}, 2 \mathrm{H},-\mathrm{OCH}_{2}-\right), 5.44(\mathrm{dd}, J=10.7,1.5 \mathrm{~Hz}, 1 \mathrm{H}), 5.62(\mathrm{dd}, J=17.3,1.5$ $\mathrm{Hz}, 1 \mathrm{H}), 6.13-6.23(\mathrm{~m}, 1 \mathrm{H},-\mathrm{CH}=\mathrm{C}), 6.70(\mathrm{~d}, J=8.5 \mathrm{~Hz}, 1 \mathrm{H}), 6.71(\mathrm{~d}, J=8.5 \mathrm{~Hz}, 1 \mathrm{H}), 7.56$ (dd, $J=8.5,8.5 \mathrm{~Hz}, 1 \mathrm{H}, \mathrm{H}-4), 10.69$ (s, $1 \mathrm{H}, \mathrm{CHO}) ;{ }^{13} \mathrm{C}$ NMR $\delta 55.8,69.2,103.8,104.8,114.3$ (C-1), 117.5, 132.1, 135.6 (C-4), 161.1, 161.5, $189.0(\mathrm{C}=\mathrm{O})$. HRMS Calcd for $\mathrm{C}_{11} \mathrm{H}_{13} \mathrm{O}_{3}$ : 193.0865 $(\mathrm{M}+1)$, found: 193.0856 .

2-(Prop-2-ynoxy)-6-methoxybenzaldehyde (9f). colorless needles; yield, $1.43 \mathrm{~g}$ (75\%); mp 97-98 ${ }^{\circ} \mathrm{C} ;{ }^{1} \mathrm{H}$ NMR $\delta 2.58$ (s, $\left.1 \mathrm{H},-\mathrm{CH}-\right), 3.89\left(\mathrm{~s}, 3 \mathrm{H},-\mathrm{OCH}_{3}\right), 4.79$ (s, 2H, $\left.-\mathrm{OCH}_{2}-\right), 6.62(\mathrm{~d}, J=$ $8.5 \mathrm{~Hz}, 1 \mathrm{H}), 6.70(\mathrm{~d}, J=8.5 \mathrm{~Hz}, 1 \mathrm{H}), 7.44$ (dd, $J=8.5,8.5 \mathrm{~Hz}, 1 \mathrm{H}, \mathrm{H}-4), 10.49$ (s, 1H, CHO); ${ }^{13} \mathrm{C}$ NMR $\delta$ 55.9, 56.4, 76.2, 77.7, 104.7, 105.3, 114.7 (C-1), 135.6 (C-4), 159.9, 161.8, 189.0 $(\mathrm{C}=\mathrm{O})$. Anal. Calcd for $\mathrm{C}_{11} \mathrm{H}_{10} \mathrm{O}_{3}: \mathrm{C}, 69.46 ; \mathrm{H}, 5.30$. Found: $\mathrm{C}, 69.70 ; \mathrm{H}, 5.50$.

Ethyl 2-(2-formyl-3-methoxyphenoxy)acetate (9g). colorless flakes (from $\mathrm{CHCl}_{3} /$ hexanes); yield, $1.50 \mathrm{~g}(63 \%) ; \mathrm{mp} 79-80{ }^{\circ} \mathrm{C} ;{ }^{1} \mathrm{H} \mathrm{NMR} \delta 1.26\left(\mathrm{t}, J=7.1 \mathrm{~Hz}, 3 \mathrm{H}, \mathrm{CH}_{3}\right), 3.90\left(\mathrm{~s}, 3 \mathrm{H}, \mathrm{OCH}_{3}\right)$, 4.22 (q, $\left.J=7.1 \mathrm{~Hz}, 2 \mathrm{H}, \mathrm{CH}_{2}\right), 4.72$ (s, 2H, $\left.\mathrm{OCH}_{2} \mathrm{CO}\right), 6.44$ (d, $\left.J=8.2 \mathrm{~Hz}, 1 \mathrm{H}\right), 6.62$ (d, $J=8.4$ 
$\mathrm{Hz}, 1 \mathrm{H}), 7.40(\mathrm{dd}, J=8.2,8.2 \mathrm{~Hz}, 1 \mathrm{H}, \mathrm{H}-4), 10.56(\mathrm{~s}, 1 \mathrm{H}, \mathrm{CHO}) ;{ }^{13} \mathrm{C} \mathrm{NMR} \delta 13.9,55.9,61.3$, 65.7, 104.6, 104.9, 114.6 (C-1), 135.5 (C-4), 160.4, 161.6, 168.0 (COO), 188.9 (CHO). Anal. Calcd for $\mathrm{C}_{12} \mathrm{H}_{14} \mathrm{O}_{5}$ : C, 60.50; H, 5.92. Found: C, 60.12; H, 6.09.

General procedure preparation of unsymmetrical 2,6-dialkoxybenzaldehydes 15a-c from 1 According to the reported procedure, ${ }^{17}$ 3-ethoxyphenol (13a) and 3butoxyphenol (13b) were obtained from 1 in $50 \%$ and $47 \%$ yields, respectively. The similar procedure as the preparation of 1-alkoxy-3-methoxybenzenes 8a-d from 7 afforded 1-iso-propoxy-3-ethoxybenzene (14a, $1.15 \mathrm{~g}, 64 \%$ based on 13a), 1-butoxy-3-ethoxybenzene (14b, $1.34 \mathrm{~g}, 69 \%$ based on 13a) and 1octyloxy-3-butoxybenzene (14c, $2.17 \mathrm{~g}, 78 \%$ based on 13b). According to the above-mentioned procedure for the formylation of $\mathbf{8 a}-\mathbf{c}$, formylation of $14 \mathbf{a}-\mathbf{c}(10 \mathrm{mmol})$ with $n$-BuLi/DMF produced $15 \mathbf{a}-\mathbf{c}$.

2-iso-Propoxy-6-ethoxybenzaldehyde (15a). colorless oil; yield, $1.31 \mathrm{~g}\left(63 \%\right.$ based on 14a); ${ }^{1} \mathrm{H}$ NMR $\delta 1.36\left(\mathrm{~d}, J=6.1 \mathrm{~Hz}, 6 \mathrm{H}, 2 \times-\mathrm{CH}_{3}\right), 1.43\left(\mathrm{t}, J=7.1 \mathrm{~Hz}, 3 \mathrm{H},-\mathrm{CH}_{3}\right), 4.07(\mathrm{q}, J=7.1 \mathrm{~Hz}$, $\left.2 \mathrm{H},-\mathrm{OCH}_{2}-\right), 4.59$ (h, $\left.J=6.1 \mathrm{~Hz}, 1 \mathrm{H},-\mathrm{OCH}-\right), 6.50$ (d, $\left.J=8.1 \mathrm{~Hz}, 1 \mathrm{H}\right), 6.54$ (d, J=8.4 Hz, 1H), $7.38(\mathrm{dd}, J=8.2 \mathrm{~Hz}, 1 \mathrm{H}, \mathrm{H}-4), 10.51(\mathrm{~s}, 1 \mathrm{H}, \mathrm{CHO}) ;{ }^{13} \mathrm{C} \mathrm{NMR} \delta 14.5,21.9,64.3,71.4,104.3$, 106.1, 115.5 (C-1), 135.4 (C-4), 160.9, 161.1, $189.7(\mathrm{C}=\mathrm{O})$. HRMS Calcd for $\mathrm{C}_{12} \mathrm{H}_{17} \mathrm{O}_{3}$ : 209.1178 (M+1), found: 209.1176.

2-Butoxy-6-ethoxybenzaldehyde (15b). colorless oil; yield, $1.71 \mathrm{~g}(77 \%$ based on $\mathbf{1 4 b}){ }^{1} \mathrm{H}$ NMR $\delta 0.94\left(\mathrm{t}, J=7.4 \mathrm{~Hz}, 3 \mathrm{H},-\mathrm{CH}_{3}\right), 1.42\left(\mathrm{t}, J=7.0 \mathrm{~Hz}, 3 \mathrm{H},-\mathrm{CH}_{3}\right), 1.48-1.54(\mathrm{~m}, 2 \mathrm{H})$, $1.78-1.83(\mathrm{~m}, 2 \mathrm{H}), 4.00\left(\mathrm{t}, J=6.3 \mathrm{~Hz}, 2 \mathrm{H},-\mathrm{OCH}_{2^{-}}\right), 4.06\left(\mathrm{t}, J=7.0 \mathrm{~Hz}, 2 \mathrm{H}, \mathrm{OCH}_{2}-\right), 6.52(\mathrm{~d}, J$ $=8.4 \mathrm{~Hz}, 1 \mathrm{H}), 6.53(\mathrm{~d}, J=8.4 \mathrm{~Hz}, 1 \mathrm{H}), 7.35(\mathrm{dd}, J=8.4,8.4 \mathrm{~Hz}, 1 \mathrm{H}, \mathrm{H}-4), 10.54(\mathrm{~s}, 1 \mathrm{H}, \mathrm{CHO})$; ${ }^{13} \mathrm{C}$ NMR $\delta 13.7,14.5,19.1,30.9,64.3,68.4,104.4$ (C-3 and C-5), 114.5 (C-1), 135.5 (C-4), 161.1, 161.6, $189.2(\mathrm{C}=\mathrm{O})$. HRMS Calcd for $\mathrm{C}_{13} \mathrm{H}_{19} \mathrm{O}_{3}: 223.1334(\mathrm{M}+1)$, found: 223.1333.

2-Butoxy-6-octyloxybenzaldehyde (15c). colorless oil; yield: $2.48 \mathrm{~g}(81 \%$ based on $14 \mathrm{c}) ;{ }^{1} \mathrm{H}$ NMR $\delta 0.88\left(\mathrm{t}, J=6.9 \mathrm{~Hz}, 3 \mathrm{H},-\mathrm{CH}_{3}\right), 0.97\left(\mathrm{t}, J=7.3 \mathrm{~Hz}, 3 \mathrm{H},-\mathrm{CH}_{3}\right), 1.28-1.31(\mathrm{~m}, 8 \mathrm{H})$, 1.44-1.55 (m, 4H), 1.75-1.84 (m, 4H), 3.99-4.05 (m, 4H), $6.53(\mathrm{~d}, J=8.5 \mathrm{~Hz}, 2 \mathrm{H}, \mathrm{H}-3$ and H5), 7.37 (dd, $J=8.5,8.5 \mathrm{~Hz}, 1 \mathrm{H}, \mathrm{H}-4), 10.54$ (s, 1H, CHO); ${ }^{13} \mathrm{C}$ NMR $\delta 13.7,14.0,19.1,22.5$, 25.9, 28.9, 29.1, 29.2, 31.0, 31.7, 68.4, 68.8, 104.4 (C-3 and C-5), 114.6 (C-1), 135.5 (C-4), 161.5, 161.6, 189.2 (C=O). HRMS Calcd for $\mathrm{C}_{19} \mathrm{H}_{31} \mathrm{O}_{3}: 307.2273(\mathrm{M}+1)$, found: 307.2272.

Procedure for the preparation of 2-butoxy-6-benzyloxybenzaldehyde (19) from 3butoxyphenol (13b): Based on the procedure for the preparation of 2-hydroxy-6methoxybenzaldehyde (12), ${ }^{16}$ 2-hydroxy-6-butoxybenzaldehyde (18) was obtained in three steps from 3-butoxyphenol (13b, $4.98 \mathrm{~g}, 30 \mathrm{mmol})$ in total 20\% yield. O-Alkylation of 18 (0.97 g, 5 mmol) with benzyl bromide $(2.14 \mathrm{~g}, 13 \mathrm{mmol})$ in the presence of $\mathrm{K}_{2} \mathrm{CO}_{3}(2.3 \mathrm{~g}$, anhydrous $)$, after usual work-up, gave 2-butoxy-6-benzyloxybenzaldehyde (19).

2-Hydroxy-6-butoxybenzaldehyde (18). Colorless oil; yield: $1.16 \mathrm{~g}, 20 \%$ based on 3butoxyphenol (13b); ${ }^{1} \mathrm{H}$ NMR $\delta 0.96\left(\mathrm{t}, J=7.5 \mathrm{~Hz}, 3 \mathrm{H},-\mathrm{CH}_{3}\right), 1.46-1.53(\mathrm{~m}, 2 \mathrm{H}), 1.75-1.82$ $(\mathrm{m}, 2 \mathrm{H}), 4.02\left(\mathrm{t}, J=6.5 \mathrm{~Hz}, 2 \mathrm{H},-\mathrm{OCH}_{2}-\right), 6.34(\mathrm{~d}, J=8.3 \mathrm{~Hz}, 1 \mathrm{H}), 6.48(\mathrm{~d}, J=8.4 \mathrm{~Hz}, 1 \mathrm{H}), 7.36$ 
(dd, $J=8.3,8.3 \mathrm{~Hz}, 1 \mathrm{H}, \mathrm{H}-4), 10.34$ (s, $1 \mathrm{H}, \mathrm{CHO}), 11.95$ (s, $1 \mathrm{H}, \mathrm{OH}) ;{ }^{13} \mathrm{C}$ NMR $\delta$ 13.7, 19.2, 30.9, 68.2, 101.6, 109.4, 110.8 (C-1), 138.3 (C-4), 162.0, 163.5, $194.3(\mathrm{C}=\mathrm{O})$. MS (EI): $194\left(\mathrm{M}^{+}\right.$, 24), $137\left(\mathrm{M}^{+}-\mathrm{C}_{4} \mathrm{H}_{9}, 100\right)$.

2-Butoxy-6-benzyloxybenzaldehyde (19). Colorless oil; yield: $0.85 \mathrm{~g}\left(60 \%\right.$ based on 18); ${ }^{1} \mathrm{H}$ NMR $\delta 0.94\left(\mathrm{t}, J=7.4 \mathrm{~Hz}, 3 \mathrm{H},-\mathrm{CH}_{3}\right), 1.47-1.54(\mathrm{~m}, 2 \mathrm{H}), 1.77-1.82(\mathrm{~m}, 2 \mathrm{H}), 3.99(\mathrm{t}, J=6.4$ $\left.\mathrm{Hz}, 2 \mathrm{H},-\mathrm{OCH}_{2}-\right), 5.15\left(\mathrm{~s}, 2 \mathrm{H}, \mathrm{PhCH}_{2}-\right), 6.54(\mathrm{~d}, J=8.4 \mathrm{~Hz}, 1 \mathrm{H}), 6.56(\mathrm{~d}, J=8.4 \mathrm{~Hz}, 1 \mathrm{H})$, 7.29-7.39 (m, 4H), 7.44 (d, $J=7.2 \mathrm{~Hz}, 2 \mathrm{H}), 10.59$ (s, 1H, CHO); ${ }^{13} \mathrm{C}$ NMR $\delta$ 13.7, 19.1, 31.0, 68.5, 70.3, 104.9, 105.0, 114.8 (C-1), 126.7, 127.7, 128.4, 135.5 (C-4), 136.3, 160.6, 161.8, $189.1(\mathrm{C}=\mathrm{O})$. Anal. Calcd for $\mathrm{C}_{18} \mathrm{H}_{20} \mathrm{O}_{3}: \mathrm{C}, 76.03 ; \mathrm{H}, 7.09$. Found: $\mathrm{C}, 75.65 ; \mathrm{H}, 7.47$.

\section{References}

1. Loev, B.; Dawson, C. R. J. Am. Chem. Soc. 1956, 78, 6095.

2. Reimann, E. Chem. Ber. 1969, 102, 2881.

3. Kimachi, T.; Tanaka, K.; Yoneda, F. J. Het. Chem. 1991, 28, 439.

4. Robinson, R.; Shah, R. C. J. Chem. Soc. 1934, 1491.

5. Larrow, J. F.; Jacobsen, E. N.; Gao, Y.; Hong, Y.; Nie, X.; Zepp, C. M. J. Org. Chem. 1994, 59, 1939.

6. Petrov, O. I.; Kalcheva, V. B.; Antonova, A. T. Collect. Czech. Chem. Commun. 1997, 62, 494.

7. Crozet, M. P.; Sabuco, J.-F.; Tamburlin, I.; Barreau, M.; Giraud, L.; Vanelle, P. Heterocycles 1993, 36, 45.

8. Ubeda, J. I.; Avendano, C.; Menendez, J. C.; Villacampa, M. Heterocycles 1994, 38, 2677.

9. Weidner-Wells, M. A.; Fraga-Spano, S. A. Synth. Commun. 1996, 26, 2775.

10. Sukuzi, Y.; Takahashi, H. Chem. Pharm. Bull. 1983, 31, 1751.

11. Bigi, F.; Conforti, M. L.; Maggi, R.; Sartori, G. Tetrahedron 2000, 56, 2709.

12. For a review, see Snieckus, V. Chem Rev. 1990, 90, 879.

13. Klumpp, G. W.; Sinnige, M. J. Tetrahedron Lett. 1986, 27, 2247.

14. Meyers, A. I.; Avila, W. B. Tetrahedron Lett. 1980, 21, 3335.

15. Winkle, M. R.; Ronald, R. C. J. Org. Chem. 1982, 47, 2101.

16. Zacharie, B.; Attardo, G.; Barriault, N.; Penney, C. J. Chem. Soc., Perkin Trans. 1 1997, 2925.

17. Klarmann, E.; Gatyas, L. W.; Shternov, V. A. J. Am. Chem. Soc. 1931, 53, 3397. 